\title{
Sensitivity and reproducibility of conventional qualitative and quantitative PCR assays for detection of the $t(14 ; 18)(q 32 ; q 21)$ chromosomal translocation in biopsy material from patients with follicular lymphoma
}

\author{
IRA KOKOVIC ${ }^{1}$, BARBARA JEZERSEK NOVAKOVIC ${ }^{2}$, \\ SNJEZANA FRKOVIC GRAZIO $^{3}$ and SRDJAN NOVAKOVIC ${ }^{1}$ \\ Departments of ${ }^{1}$ Molecular Diagnostics, ${ }^{2}$ Medical Oncology and ${ }^{3}$ Pathology, \\ Institute of Oncology Ljubljana, Zaloska 2, 1000 Ljubljana, Slovenia
}

Received August 22, 2008; Accepted October 10, 2008

DOI: 10.3892/ijmm_00000096

\begin{abstract}
Follicular lymphoma (FL) is characterized by the $\mathrm{t}(14 ; 18)(\mathrm{q} 32 ; \mathrm{q} 21)$ chromosomal translocation which can be detected by polymerase chain reaction (PCR) in approximately $70 \%$ of cases. The aim of our retrospective study was to evaluate the sensitivity and the reproducibility of both conventional qualitative and quantitative PCR assays for detection of the $\mathrm{t}(14 ; 18)(\mathrm{q} 32 ; \mathrm{q} 21)$ chromosomal translocation in biopsy material. Fifty-seven formalin-fixed, paraffinembedded tumor lymph node (LN) specimens from 50 patients with FL were included in the study. Qualitative PCR was performed with primer sets specific for the MBR, far3'-MBR and the mcr regions, respectively. Quantitative PCR was performed using the LightCycler ${ }^{\circledR}$ instrument and the LightCycler $^{\circledR}-\mathrm{t}(14 ; 18)$ Quantification Kit (MBR). The overall detection rate of the $t(14 ; 18)$ in our study $(52.6 \%)$ was in accordance with the literature. Of the $\mathrm{t}(14 ; 18)$-positive cases, $49.1 \%$ had breakpoints within the MBR and only $3.5 \%$ had breakpoints within the mcr. The most sensitive method was LightCycler-based PCR with a detection rate of $47.4 \%$, followed by $\mathrm{MBR}_{1,2}$ assay (43.9\%). We observed good agreement between qualitative $\mathrm{MBR}_{1,2}$ and quantitative LightCycler-based assay with a slightly higher detection rate of the quantitative method. The sensitivities of both methods were in accordance with results from other studies. Since LightCycler-based assay detects only breakpoints within the MBR, qualitative PCR should be employed in routine diagnostic settings for detection of breakpoints within the mor and far3'-MBR regions.
\end{abstract}

Correspondence to: Professor Srdjan Novakovic, Department of Medical Oncology, Institute of Oncology Ljubljana, Zaloska 2, 1000 Ljubljana, Slovenia

E-mail: snovakovic@onko-i.si

Key words: follicular lymphoma, $\mathrm{t}(14 ; 18)$ chromosome translocation, $B C L-2$ rearrangement, polymerase chain reaction, paraffinembedded tissue

\section{Introduction}

Follicular lymphoma (FL), one of the most common nonHodgkin's lymphomas of B-cell type in the Western population, is characterized by the $\mathrm{t}(14 ; 18)(\mathrm{q} 32 ; \mathrm{q} 21)$ chromosomal translocation in approximately $80 \%$ of cases (1). This chromosomal translocation juxtaposes the $B C L-2$ locus on chromosome $18 \mathrm{q} 32.3$ to the immunoglobulin heavy chain gene $(I g H)$ locus on chromosome $14 q 32.33(2,3)$. Breakpoints on chromosome 14 are often clustered near the 5 ' end of one of the six $\mathrm{J}_{\mathrm{H}}$ gene segments (2-4). On the other hand, most of the breakpoints on chromosome 18 are clustered within two primary breakpoint regions, the major breakpoint region $(\mathrm{MBR})$ and the minor cluster region (mcr) $(2,4,5)$. Approximately $50-60 \%$ of the $B C L-2$ rearrangements in FL occur within the MBR (5) and 10-20\% of rearrangements occur within the mcr (6). Other breakpoint regions within the $B C L-2$ locus have also been identified (7-9). Approximately $8 \%$ of breakpoints occur within the far3'-MBR subcluster region and 3-4\% of breakpoints occur within the 5'-mcr subcluster region (7-9).

These restricted breakpoint localizations have allowed the design of primers specific for 5 ' regions of the MBR and mor clusters on chromosome 18 , and for conserved portions of the $\mathrm{J}_{\mathrm{H}}$ gene segments on chromosome 14, which have been widely used for standard polymerase chain reaction (PCR) assays $(7,10)$. The combination of standard MBR and mor primers with a $\mathrm{J}_{\mathrm{H}}$ consensus primer enables the detection of approximately $70 \%$ of $B C L-2 / \mathrm{J}_{\mathrm{H}}$ rearrangements $(7,10)$. Various methodologies in performing PCR with different primer sequences, methods of amplification and detection of amplified products have been described $(7,8,10-12)$. Recently, quantitative real-time PCR has been extensively employed in most laboratories, particularly for detection of minimal residual disease (MRD) in follow-up of patients (13-22). The sensitivities of described methods vary greatly, mostly depending on the methodology (qualitative vs quantitative, single-round vs nested PCR) and choice of primers (10). Most previous studies were performed using DNA isolated from fresh peripheral blood or bone marrow aspirates 
(12-16,19-23) and only a few studies used DNA derived from formalin-fixed, paraffin-embedded tissue specimens $(11,21,23,24)$.

The aim of our retrospective study on a series of archival specimens from Slovenian patients with FL was to evaluate the sensitivity and the reproducibility of both conventional qualitative and quantitative PCR assays for detection of the $\mathrm{t}(14 ; 18)(\mathrm{q} 32 ; \mathrm{q} 21)$ chromosomal translocation. Furthermore, we compared different MBR-based PCR assays in order to determine the most useful PCR approach for detection of $\mathrm{t}(14 ; 18)$ with breakpoints in the MBR on biopsy material.

\section{Materials and methods}

Study group. Fifty-seven tumor lymph node (LN) specimens from 50 patients with follicular lymphoma (FL), diagnosed and treated at the Institute of Oncology, Ljubljana, over the period 1993-2005, were included in this retrospective study. There were 16 male and 34 female patients. Median age at the time of lymphoma diagnosis was 51 years. Histological classification of FL was performed according to the World Health Organization classification. All tumor samples that had been formerly classified by the Kiel or REAL classifications were reclassified according to the WHO classification. Thirteen patients had follicular lymphoma grade I, 17 patients grade II, 15 patients grade IIIA and 5 patients grade IIIB. All tumor LN samples were fixed in phosphate-buffered formalin (PBF) and embedded in paraffin (FFPE tissue samples).

Reactive lymph nodes from 15 patients were used as a negative control group for detection of the $\mathrm{t}(14 ; 18)(\mathrm{q} 32 ; \mathrm{q} 21)$ translocation and B-cell clonality.

DNA isolation. Five paraffin sections $(10 \mu \mathrm{m})$ from each specimen were available for the study. DNA was isolated using the High Pure PCR Template Preparation kit (Roche Applied Science, Penzberg, Germany) according to the manufacturer's protocol with slight modifications in the deparaffinization step. The concentration and the purity of DNA $\left(\mathrm{A}_{260 \mathrm{~nm}} / \mathrm{A}_{280 \mathrm{~nm}}\right)$ were determined spectrophotometrically.

Conventional qualitative PCR. Qualitative single-round PCR for $\mathrm{t}(14 ; 18)$ translocation was performed with two different primer sets for detection of breakpoints in the major breakpoint region (MBR), and two primer sets for detection of breakpoints in the far3'-MBR and the minor cluster region (mcr) of the $B C L-2$ oncogene. MBR primer sets were $\mathrm{MBR} / \mathrm{J}_{\mathrm{Ha}}$ and, $\mathrm{MBR}_{1}$ and $\mathrm{MBR}_{2}$ in a multiplex PCR with $\mathrm{J}_{\mathrm{Ha}}$ primer. The far3'-MBR and mor primers were also used in the two multiplex reactions with the $\mathrm{J}_{\mathrm{Ha}}$ primer. The MBR primer was chosen according to Slack et al (25), $\mathrm{MBR}_{1}$ and $\mathrm{MBR}_{2}$, far3'-MBR and mcr primers were proposed by P. Rombout, University Medical Centre Nijmegen (personal communication) and the $\mathrm{J}_{\mathrm{Ha}}$ primer was chosen according to Segal et al (26). Expected sizes of amplified fragments are 100-270 bp in the case of breakpoints in the MBR, and 150-500 bp in the case of breakpoints in the far3'-MBR and the mcr.

All specimens were also subjected to B-cell clonality analysis using the consensus primers $\mathrm{V}_{\mathrm{H}}$-FRIII, with a reported homology of at least $85 \%$ with published $\mathrm{V}_{\mathrm{H}}$ gene sequences, and $\mathrm{J}_{\mathrm{H}}$, which anneal to variable and joining gene segments of the immunoglobulin heavy chain gene $(\operatorname{IgH})$, respectively (25).

Each run included appropriate positive [DNA from cell lines Su-DHL6, SC1, OZ and K231, or patient samples with confirmed translocation $\mathrm{t}(14 ; 18)$ ], negative (DNA from reactive lymph nodes) and contamination (no DNA template) controls. Furthermore, the DNA quality of each extract was tested in an internal control amplification using primers specific for the ubiquitously expressed B-globin gene (172-bp amplicon) or the exon 19 of the MLH1 gene (289-bp amplicon). All patient specimens were analyzed in duplicate by each PCR. In a case of discrepant results by particular PCR (pos/neg), analysis was repeated and the result of the third test was considered as final.

Detection sensitivity of $\mathrm{MBR} / \mathrm{J}_{\mathrm{Ha}}$ and $\mathrm{MBR}_{1,2} \mathrm{PCR}$ assays was tested by analyzing serial dilutions of positive control DNA derived from the Su-DHL6 cell line in sterile PCR grade water $\left(1: 5,1: 10,1: 20,1: 50,1: 100,1: 10^{3}, 1: 10^{4}, 1: 10^{5}\right.$ and $1: 10^{6}$ ), and by mixing Su-DHL6 DNA with the DNA derived from reactive lymph node, with previously confirmed polyclonality of B cells and the absence of $t(14 ; 18)$ (the same ratios as in water dilutions). Starting concentrations of both DNA preparations were adjusted to $\sim 250 \mathrm{ng} / \mu \mathrm{l}$. We did not evaluate the sensitivity of mcr and far3'-MBR PCR assays, since no positive controls other than the diluted PCR products were available.

LightCycler ${ }^{\circledR}$-based quantitative real-time PCR ( $\left.q P C R\right)$. Quantitative real-time PCR was performed using the LightCycler $^{\circledR}-\mathrm{t}(14 ; 18)$ Quantification Kit (MBR) (Roche Applied Science), specifically adapted for detection of the $\mathrm{t}(14 ; 18)$ with breakpoints in the MBR, according to the manufacturer's instructions. The sensitivity of the method is one $\mathrm{t}(14 ; 18)$-bearing cell in 50,000-100,000 peripheral blood mononuclear cells.

Statistical analysis. Agreement between alternative MBR methods was measured using Cohen's $\kappa$ coefficient (a method of comparison study for categorical data) (27). A value of 0 for $\kappa$ indicates no agreement beyond chance and a value of 1 indicates perfect agreement. $\kappa$-values $<0.20$ were considered as poor agreement, values between 0.21 and 0.40 as fair, values between 0.41 and 0.60 as moderate, values between 0.61 and 0.80 as good and values $>0.81$ as very good agreement (27). Frequencies of PCR positivity were used for statistical analysis of PCR data.

\section{Results}

Sensitivity of qualitative MBR PCR assays. The sensitivity of MBR-PCR assays varied depending on whether positive control DNA (Su-DHL6 cell line) was diluted in sterile water or with the DNA derived from reactive lymph node. The $\mathrm{MBR}_{1,2}$ PCR assay showed greater sensitivity in the water dilution experiment with the detection rate of $10^{-5}$ compared to the detection rate of $10^{-3}$ by $M B R / J_{\mathrm{Ha}}$ PCR. Sensitivities of both MBR assays were lower in the dilution experiments with DNA derived from reactive lymph node, where the detection limit for both assays was $10^{-2}$. Sensitivities of 

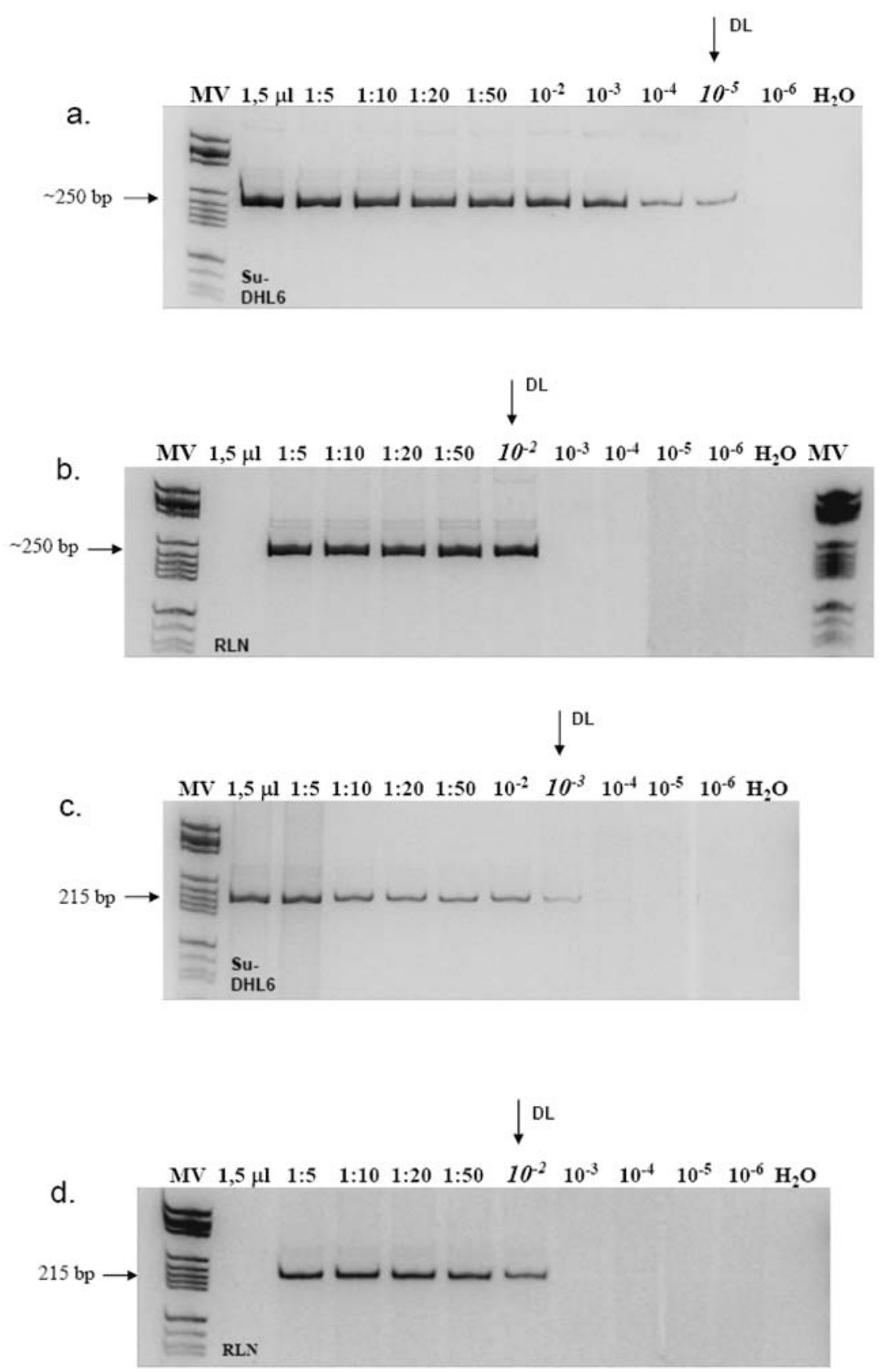

Figure 1. The sensitivity of $\mathrm{MBR}_{12}$ and $\mathrm{MBR} / \mathrm{J}_{\mathrm{Ha}}$ PCR. $\mathrm{MBR}_{1,2}$ PCR: Su-DHL6 DNA diluted in $\mathrm{H}_{2} \mathrm{O}$ (a). MBR ${ }_{12}$ PCR: Su-DHL6 DNA diluted with reactive LN DNA (b). MBR/J $\mathrm{Ha}_{\mathrm{a}}$ PCR: Su-DHL6 DNA diluted in $\mathrm{H}_{2} \mathrm{O}$ (c). MBR/J $\mathrm{Ha}_{\mathrm{Ha}}$ PCR: Su-DHL6 DNA diluted with reactive LN DNA (d). MV, pBR322/HaeIII; SuDHL6, lymphoma cell line (positive control); RLN, reactive lymph node; DL, detection limits of $\mathrm{MBR}_{1,2}$ and $\mathrm{MBR} / \mathrm{J}_{\mathrm{Ha}} \mathrm{PCR}$ assays.

$\mathrm{MBR}_{1,2}$ and $\mathrm{MBR} / \mathrm{J}_{\mathrm{Ha}}$ PCRs in the dilution experiments are shown in Fig. 1.

Tumor lymph node specimens. Valuable results were obtained for all 57 paraffin-embedded lymph node (LN) specimens from 50 patients.

Detection of the t(14;18)(q32;q21) chromosome translocation. The results of PCR detection of the $\mathrm{t}(14 ; 18)$ were highly reproducible. Initially, all specimens were analyzed in duplicate showing the same result in parallel tests. Furthermore, at the end of the study we repeated the analysis of all specimens initially positive for MBR breakpoints and found $100 \%$ agreement of results.
We detected the $t(14 ; 18)$ in 30 of $57(52.6 \%)$ specimens by using described methods. Twenty-eight specimens (49.1\%) had breakpoints within the MBR and 2 (from 2 patients; $3.5 \%$ ) had breakpoints within the mcr. There were no breakpoints found within the far3'-MBR. Detection rates of different MBR methods were $31.6 \%$ (18/57) for $\mathrm{MBR} / \mathrm{J}_{\mathrm{Ha}}$ PCR, $43.9 \%$ $(25 / 57)$ for $\mathrm{MBR}_{1,2} \mathrm{PCR}$ and $47.4 \%$ (27/57) for quantitative LC-based PCR.

Comparison of different MBR methods. In order to determine the most appropriate MBR method for analysis of biopsy material, we compared the effectiveness of each assay: $\mathrm{MBR} / \mathrm{J}_{\mathrm{Ha}}, \mathrm{MBR}_{1,2}$ and quantitative LightCycler-based PCR (LC) for 28 PCR-positive specimens: 64.3\% (18/28), 89.3\% 

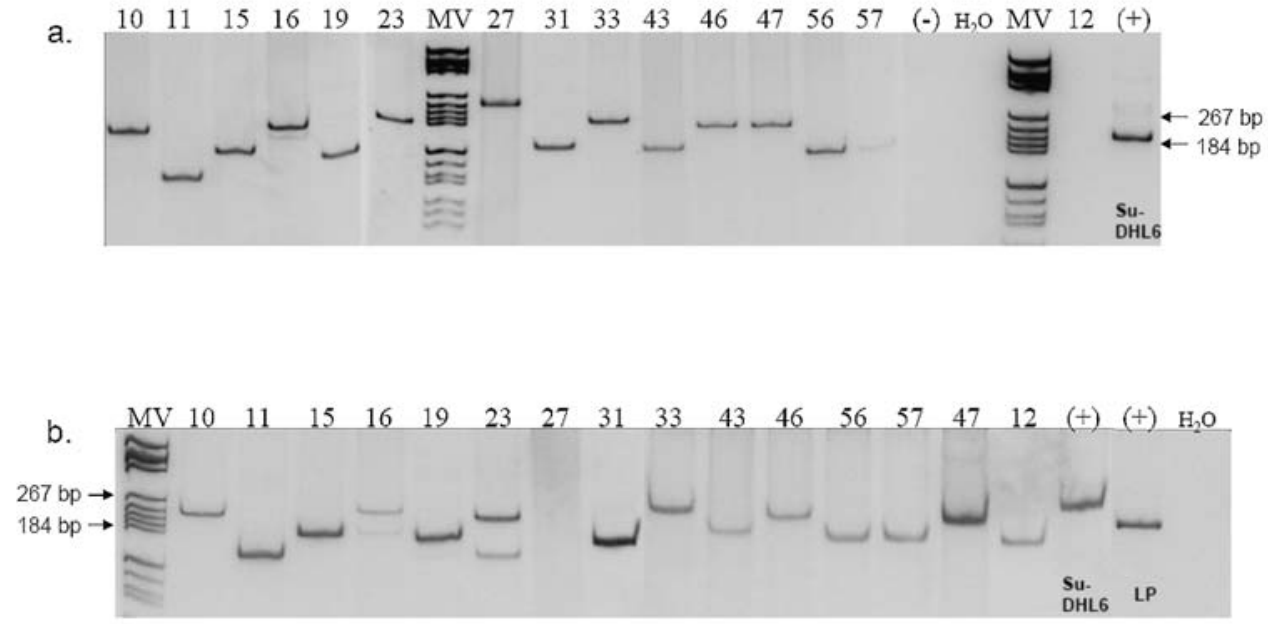

Figure 2. Detection of the $t(14 ; 18)(q 32 ; q 21)$ with breakpoints in the MBR by two sets of primers: $M B R / J_{\text {На }}$ (a) and $M_{B R R}$ (b). MV, pBR322/HaeIII; (+), positive controls [DNA from Su-DHL6 cell line and from a patient (LP) with previously confirmed $t(14 ; 18)$ ]; (-), negative control [DNA from reactive lymph node with previously confirmed absence of $\mathrm{t}(14 ; 18)] ; \mathrm{H}_{2} \mathrm{O}$, contamination control (no DNA template). Numbers above each lane represent lymph node specimens. Sample 27 (patient 33) was negative by $\mathrm{MBR}_{1,2}$ PCR, but was positive in repeated analysis. Samples 46 and 47 belong to the same patient (patient 1 ). Sample 12 (patient 8 ) was negative by $\mathrm{MBR} / \mathrm{J}_{\mathrm{Ha}}$ but positive by $\mathrm{MBR}_{1,2} \mathrm{PCR}$.

Table I. Detection of MBR breakpoints in 28 positive LN biopsy specimens.

\begin{tabular}{|c|c|c|c|c|}
\hline No. and type of method & No.(+) & $\%$ & Total no.(+) & $\%$ \\
\hline \multicolumn{5}{|l|}{ Three MBR methods } \\
\hline $\mathrm{MBR} / \mathrm{J}_{\mathrm{Ha}}+\mathrm{MBR}_{1,2}+\mathrm{LC}$ & 18 & 64.3 & 18 & 64.3 \\
\hline \multicolumn{5}{|l|}{ Two MBR methods } \\
\hline $\mathrm{MBR} / \mathrm{J}_{\mathrm{Ha}}+\mathrm{MBR}_{1,2}$ & 0 & 0.0 & 6 & 21.4 \\
\hline $\mathrm{MBR} / \mathrm{J}_{\mathrm{Ha}}+\mathrm{LC}$ & 0 & 0.0 & & \\
\hline $\mathrm{MBR}_{1,2}+\mathrm{LC}$ & 6 & 21.4 & & \\
\hline \multicolumn{5}{|l|}{ One MBR method } \\
\hline $\mathrm{LC}$ & 3 & 10.7 & 4 & 14.3 \\
\hline $\mathrm{MBR}_{1,2}$ & 1 & 3.6 & & \\
\hline $\mathrm{MBR} / \mathrm{J}_{\mathrm{Ha}}$ & 0 & 0.0 & & \\
\hline Total & & & 28 & 100.0 \\
\hline
\end{tabular}

No.(+), number of cases positive by particular MBR method(s); total no.(+), total number of cases positive by three, two and one MBR method, respectively.

(25/28) and 96.4\% (27/28), respectively. Eighteen of the 28 specimens $(64.3 \%)$ were positive by all three MBR methods, $6 / 28(21.4 \%)$ were positive by two methods and 4/28 (14.3\%) were positive by only one MBR method (Table I). Very good agreement was found between the $\mathrm{MBR}_{1,2}$ and LC method (Cohen's $\kappa$ coefficient was 0.854). A good agreement was found between $\mathrm{MBR} / \mathrm{J}_{\mathrm{Ha}}$ and $\mathrm{MBR}_{1,2} \mathrm{PCR}(\kappa=0.737)$ as well as between MBR/ $\mathrm{J}_{\mathrm{Ha}}$ and LC PCR $(\kappa=0.671)$. Agreements expected by chance would be $92.7,87.2$ and $83.6 \%$, respectively. Examples of qualitative MBR and mcr PCRs are shown in Figs. 2 and 3. An example of the amplification curve obtained by LightCycler-based PCR is shown in Fig. 4.
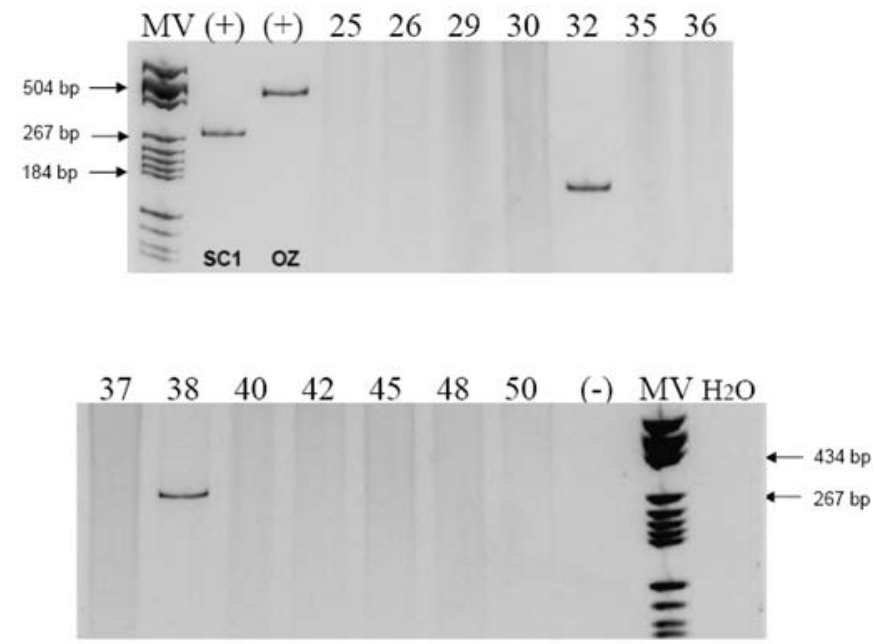

Figure 3. Detection of the $\mathrm{t}(14 ; 18)(\mathrm{q} 32 ; \mathrm{q} 21)$ with breakpoints in the mcr. MV, pBR322/HaeIII; (+), positive controls (1:100 and 1:10 diluted PCR products from SC1 and $\mathrm{OZ}$ cell lines, respectively); (-), negative control [DNA from reactive lymph node with previously confirmed absence of $\mathrm{t}(14 ; 18)] ; \mathrm{H}_{2} \mathrm{O}$, contamination control (no DNA template). Numbers above each lane represent lymph node specimens. Samples 32 (patient 7) (a) and 38 (patient 29) (b) were positive for the $t(14 ; 18)$ with breakpoints within the mer.

Clonality analysis by IgH-FRIII PCR. We determined the clonality in $54 / 57(94.7 \%)$ specimens. Sixteen specimens (28.1\%) were monoclonal, $33(57.9 \%)$ were polyclonal and 5 $(8.8 \%)$ were interpreted as 'monoclonal in a polyclonal background' $(\mathrm{M} / \mathrm{P})$. We could not determine the clonality in $3(5.3 \%)$ specimens, since we detected neither amplified products nor smears from polyclonally rearranged $\mathrm{IgH}$ genes. Notably, these 3 specimens were positive for both control genes B-globin and the MLH1-exon 19 fragment, suggesting that the quality of DNA was appropriate for PCR amplification. 

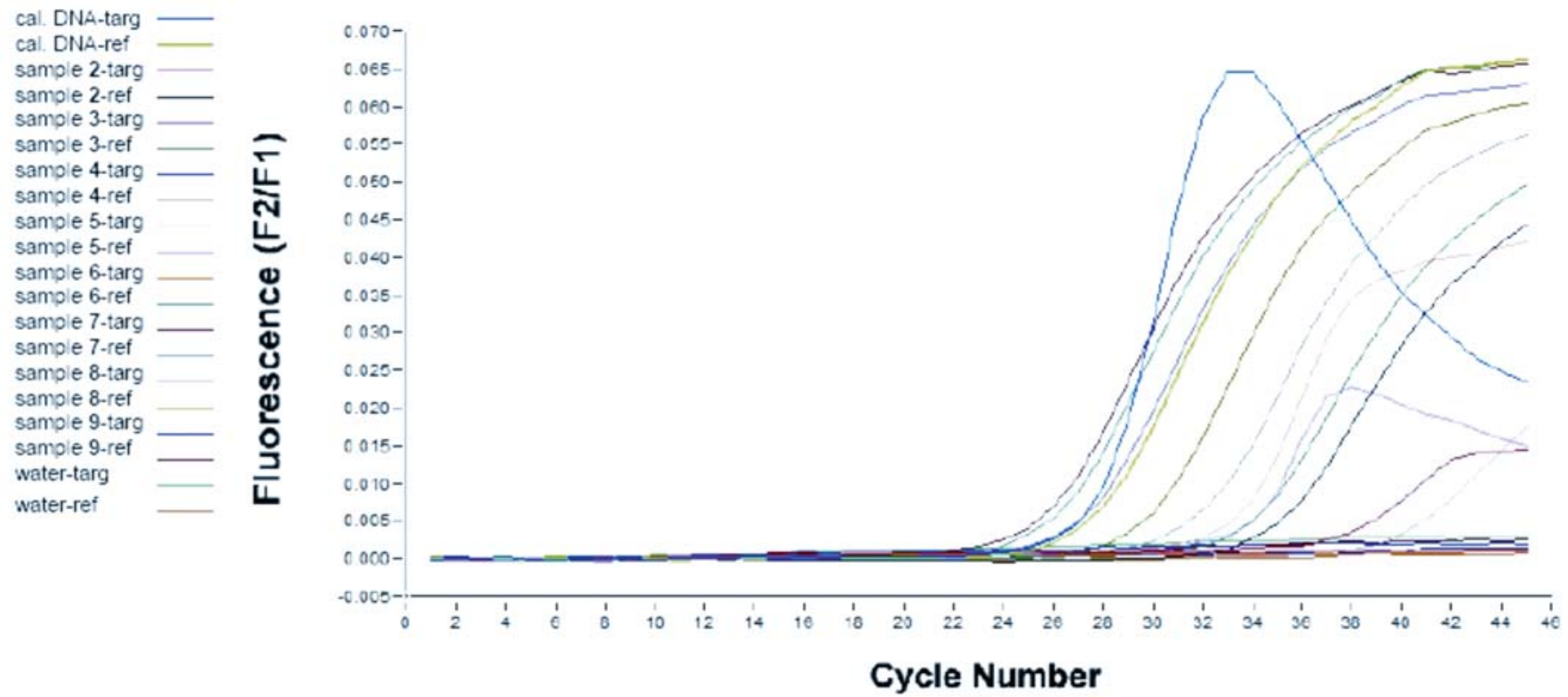

Figure 4. The amplification curve obtained by using the LightCycler ${ }^{\circledR}$ - $t(14 ; 18)$ Quantification Kit (MBR). Sample ( 50 ng) and calibrator (DOHH2) DNA were analyzed. Lymph node samples 2, 5, 8 and 9 were positive and samples 3, 4, 6 and 7 were negative. Normalized ratios T:R (target to reference gene copies) were $0.03,0.01,0.06$ and $<0.01$ for samples $2,5,8$ and 9 , respectively. The normalized ratio for the calibrator was set to value 1.0 .

Table II. Clonality status and the presence of the $\mathrm{t}(14 ; 18)$ (q32;q21) in 57 LN biopsy specimens.

\begin{tabular}{lrrrcc}
\hline Clonality & $\begin{array}{c}\text { No. of } \\
\text { cases }\end{array}$ & \% & $\mathrm{t}(14 ; 18)^{+}$ & $\% \mathrm{t}^{+}$of total & $\begin{array}{c}\% \mathrm{t}^{+} \text {of } \\
\mathrm{M} ; \mathrm{M} / \mathrm{P} ; \mathrm{P}\end{array}$ \\
\hline $\mathrm{M}$ & 16 & 28.1 & 10 & 17.5 & 62.5 \\
$\mathrm{M} / \mathrm{P}$ & 5 & 8.8 & 2 & 3.5 & 40.0 \\
$\mathrm{P}$ & 33 & 57.9 & 16 & 28.1 & 48.5 \\
$\mathrm{ND}$ & 3 & 5.3 & 2 & 3.5 & 66.7 \\
Total & 57 & 100.0 & 30 & 52.6 & \\
\hline
\end{tabular}

$\mathrm{M}$, monoclonal; $\mathrm{M} / \mathrm{P}$, 'monoclonal in a polyclonal background'; $\mathrm{P}$, polyclonal; ND, not determined.

We compared the presence of the $\mathrm{t}(14 ; 18)(\mathrm{q} 32 ; \mathrm{q} 21)$ chromosome translocation with the clonality status (Table II). Of the monoclonal cases, 10 were positive for the $t(14 ; 18)(9$ with breakpoints within the MBR and one within the mcr), and of the polyclonal cases, 16 were positive (all with breakpoints within the MBR). Two M/P cases were also positive for the $t(14 ; 18)$ (one had breakpoint within the MBR and one within the mcr). Two of 3 cases for which clonality could not be determined were positive for the $t(14 ; 18)$, both with breakpoints within the MBR.

Negative control group. All 15 reactive lymph node specimens (from 15 patients) were negative by qualitative $\mathrm{MBR} / \mathrm{J}_{\mathrm{Ha}}$, $\mathrm{MBR}_{1,2}$, mcr and far3'-MBR PCRs and polyclonal by IgHFRIII PCR. Notably, 4/15 (26.7\%) samples were positive by quantitative LightCycler-based PCR, although in the quanti- fication analysis normalized ratios of target to reference gene copies for those 4 samples were $<0.01$, suggesting the low number of $\mathrm{t}(14 ; 18)$-bearing cells.

\section{Discussion}

Numerous studies have been undertaken to estimate the usefulness of PCR-based assays for detection of the $\mathrm{t}(14 ; 18)(\mathrm{q} 32 ; \mathrm{q} 21)$ chromosomal translocation and relative quantification of $\mathrm{t}(14 ; 18)$-bearing cells in patients with follicular lymphoma (FL). Here we present the results of both qualitative and quantitative detection of the $t(14 ; 18)$ in a retrospective study on a rather large series of lymph node biopsy specimens from Slovenian patients with FL.

We evaluated the sensitivity and the reproducibility of both qualitative and quantitative approaches. The qualitative PCR assays used in our study enabled the detection of breakpoints in three important breakpoint regions: the MBR, the far3'-MBR and the mcr, while the quantitative PCR approach enabled the detection of breakpoints only in the MBR.

Before applying PCR assays on patient specimens, we estimated the sensitivity of qualitative MBR PCRs by analyzing serial dilutions of positive control DNA. The sensitivity of the $\mathrm{MBR}_{1,2}$ assay in the water dilution experiment ( 1 cell in $10^{5}$ ) was in agreement with the results from other laboratories (11), but the sensitivity of the $\mathrm{MBR} / \mathrm{J}_{\mathrm{Ha}}$ assay in the same experiment was two logs lower $\left(1\right.$ cell in $\left.10^{3}\right)$. A higher sensitivity of $\mathrm{MBR}_{1,2}$ assay was expected, since it utilizes two MBR-primers in one reaction, in contrast to $\mathrm{MBR} / \mathrm{J}_{\mathrm{Ha}}$ assay, which is a classical single-round PCR with one forward (MBR) and one reverse $\left(\mathrm{J}_{\mathrm{H}}\right)$ primer. Johnson et al (10) showed in an international multicentre study that the cut-off in the detection by single-round PCR is 1 cell in $10^{4}$ in most laboratories. The sensitivity of different PCR assays in this 
study (10) was tested by analyzing blood samples from healthy donors with varying numbers of $\mathrm{t}(14 ; 18)$-bearing cells added from a cell line with a breakpoint in the MBR (DOHH2). Thus, the estimation of sensitivity by analyzing serial dilutions of positive control DNA (Su-DHL6) with negative control DNA (reactive lymph node) is more accurate, although the sensitivity of both MBR assays in our hands was lower than expected [one $t(14 ; 18)$-positive cell in 100 negative cells]. We did not evaluate the sensitivity of two other qualitative assays, the mor and the far3'-MBR, because of the lack of appropriate positive controls. As positive controls for these two assays we utilized diluted PCR products obtained by amplifying DNA from cell lines with confirmed breakpoints in the mcr and the far3'-MBR. We also did not evaluate the sensitivity of the LightCyclerbased PCR since we used a commercial kit with a previously defined sensitivity.

The overall detection rate of the $\mathrm{t}(14 ; 18)$ in our study was $52.6 \%(30 / 57)$. Of the $\mathrm{t}(14 ; 18)$-positive specimens $49.1 \%$ (28/57) had breakpoints within the MBR and only $3.5 \%$ $(2 / 57)$ had breakpoints within the mcr. In order to improve the overall detection rate of $\mathrm{MBR} / \mathrm{J}_{\mathrm{H}}$ rearrangements, we employed three different PCR approaches, two qualitative $\left(\mathrm{MBR} / \mathrm{J}_{\mathrm{Ha}}\right.$ and $\mathrm{MBR}_{1,2}$ ) and one quantitative (LightCycler-based) assay. Supporting our expectations, the most sensitive method was LightCycler-based PCR with the detection rate of $47.4 \%$ (27/57), followed by $\mathrm{MBR}_{1,2}$ assay with the detection rate of $43.9 \%(25 / 57)$. The $\mathrm{MBR} / \mathrm{J}_{\mathrm{Ha}}$ assay had the lowest detection rate in our series, $31.6 \%(18 / 57)$. The results of our study are in agreement with other reports. Albinger-Hegyi et al (7) reported a $t(14 ; 18)$ detection rate of $36 \%$ by standard $M B R / J_{H}$ and $\mathrm{mcr} / \mathrm{J}_{\mathrm{H}}$ PCR assays applied on frozen tissue specimens from 59 patients with FL. In this study (7) 19 cases (32.2\%) had breakpoints within the MBR and only 2 cases (3.4\%) had breakpoints within the mcr. Tysarowski et al (19) detected $\mathrm{MBR} / \mathrm{J}_{\mathrm{H}}$ rearrangements in peripheral blood of $41 \%(31 / 75)$ patients with FL by nested PCR. Similarly, Mahfouz et al (24) reported 45.2\% (19/42) t(14;18)-positive cases by using the BCL2/J $\mathrm{J}_{\mathrm{H}}$ Translocation Assay (InVivoScribe Technologies, CA, USA) on formalin-fixed, paraffin-embedded specimens. The majority of the cases in this study (24) were positive for the MBR $(40.5 \%)$, whereas only 2 cases $(4.8 \%)$ were positive for the mcr. Other investigators reported detection rates of $40-60 \%$ by $\mathrm{MBR} / \mathrm{J}_{\mathrm{H}}$ PCR $(26,28)$ and $10-20 \%$ by $\mathrm{mcr} / \mathrm{J}_{\mathrm{H}}$ PCR (28). There are few data concerning the efficiency of qualitative real-time PCR assays. Dessars et al (18) reported a detection rate of $56 \%(18 / 32)$ using TaqMan technology, similar to findings of Luthra and co-researchers (29), who reported a detection rate of $54 \%(13 / 24)$ using the same approach. We could not find any data regarding detection rates by LightCycler-based PCR, since very few studies employing this technique evaluated the sensitivity of the method and it's usefulness for monitoring the minimal residual disease in the follow-up of patients with $\operatorname{FL}(20,22)$. Quantification analysis of cases positive for $\mathrm{t}(14 ; 18)$ by LightCycler PCR in our study showed values of normalized ratios of target to reference gene copies [t $(14 ; 18) / \mathrm{tPA}$ ] between 0.01 and 0.84 , which are comparable to other studies (20).
The results in the negative control group consisting of 15 reactive lymph node specimens (from 15 patients) are in agreement with reports from the literature. Although all specimens were $t(14 ; 18)$-negative by qualitative methods, we detected $26.7 \%$ (4/15) positive specimens by the more sensitive, quantitative method. Occasional benign $\mathrm{t}(14 ; 18)-$ bearing cells are present in low frequency in $30-40 \%$ of normal individuals $(30,31)$. Usually, the low frequency of $\mathrm{t}(14 ; 18)$ in benign tissues is below the level of detection using conventional qualitative PCR methods (28), but is detectable by highly sensitive quantitative tests, thus representing the potential for false-positive results (30-32).

In order to obtain additional information on our series of follicular lymphomas, we performed clonality analysis in all cases. Although we expected to find monoclonality in a larger number of cases, there were only $28.1 \%$ of monoclonal specimens. Furthermore, we could not determine the clonality in 3 specimens (5.3\%), although amplification of control genes suggested that the quality of DNA was appropriate for PCR analysis. Possibly, these cases were missed by standard IgHFRIII PCR. Several mechanisms interfere with the detection of a clonal population with IgH-FRIII PCR, including inefficient recognition of certain $\mathrm{V}_{\mathrm{H}}$ families by the consensus FRIII primer, incorrect or incomplete $\operatorname{IgH}$ gene rearrangements and mutations in the IgH locus (33). Furthermore, follicular lymphomas are characterized by the presence of abundant polyclonal B cells, which might mask the monoclonal population (33). To note, 2 of 3 specimens for which clonality could not be determined were positive for the $t(14 ; 18)$.

In conclusion, we evaluated the sensitivity and effectiveness of qualitative and quantitative PCR assays for the detection of the $\mathrm{t}(14 ; 18)(\mathrm{q} 32 ; \mathrm{q} 21)$ in lymph node biopsy specimens. We found good agreement between qualitative $\mathrm{MBR}_{1,2}$ and quantitative LightCycler ${ }^{\circledR}$-based assay with a slightly higher detection rate of the quantitative method. Sensitivities of both methods in our hands were in agreement with results from other studies. Since LightCycler-based assay detects only breakpoints within the MBR, qualitative PCR should be employed in routine diagnostic settings for detection of breakpoints within the mcr and far3'-MBR regions.

\section{Acknowledgements}

The authors would like to thank Mr. Paul Rombout and Prof. Dr Han J.J. van Krieken (University Medical Centre Nijmegen, The Netherlands), and to Dr Matej Bracko (Department of Pathology, Institute of Oncology Ljubljana). The research grant from the Slovenian Ministry of Science and Technology (J3-6363) and the financial support of the Roche Applied Science representative in Slovenia are gratefully acknowledged.

\section{References}

1. Jaffe ES, Harris NL, Stein H and Vardiman JW: Tumours of haematopoietic and lymphoid tissues. World Health Organization Classification of Tumours. IARC Press, Lyon, 2001.

2. Cleary ML and Sklar J: Nucleotide sequence of a $t(14 ; 18)$ chromosomal breakpoint in follicular lymphoma and demonstration of a breakpoint-cluster region near a transcriptionally active locus on chromosome 18. Proc Natl Acad Sci USA 82: 7439-7443, 1985. 
3. Tsujimoto Y, Finger LR, Yunis J, Nowell PC and Croce CM: Cloning of the chromosome breakpoint of neoplastic B cells with the $\mathrm{t}(14 ; \mathrm{q} 18)$ chromosome translocation. Science 226 : 1097-1099, 1984.

4. Bakshi A, Wright JJ, Graninger W, et al: Mechanism of the $\mathrm{t}(14 ; 18)$ chromosomal translocation: Structural analysis of both derivative 14 and 18 reciprocal partners. Proc Natl Acad Sci USA 84: 2396-2400, 1987.

5. Cleary ML, Galili N and Sklar J: Detection of a second t(14;18) breakpoint cluster region in human follicular lymphomas. J Exp Med 164: 315-320, 1986.

6. Ngan BY, Nourse J and Cleary ML: Detection of chromosomal translocation $\mathrm{t}(14 ; 18)$ within the minor cluster region of bcl-2 by polymerase chain reaction and direct genomic sequencing of the enzymatically amplified DNA in follicular lymphomas. Blood 73: 1759-1762, 1989

7. Albinger-Hegyi A, Hochreutener B, Abdou MT, et al: High frequency of $\mathrm{t}(14 ; 18)$-translocation breakpoints outside of major breakpoint and minor cluster regions in follicular lymphomas. Am J Pathol 160: 823-832, 2002.

8. Akasaka T, Akasaka H, Yonetani N, Ohno H, Yamabe H, Fukuhara S and Okuma M: Refinement of the BCL2/ immunoglobulin heavy chain fusion gene in $\mathrm{t}(14 ; 18)(\mathrm{q} 32 ; \mathrm{q} 21)$ by polymerase chain reaction amplification for long targets. Genes Chromosomes Cancer 21: 17-29, 1998.

9. Tsujimoto Y, Bashir MM, Givol I, Cossman J, Jaffe E and Croce CM: DNA rearrangements in human follicular lymphoma can involve the $5^{\prime}$ or the $3^{\prime}$ region of the bcl-2 gene. Proc Natl Acad Sci USA 84: 1329-1331, 1987.

10. Johnson PW, Swinbank K, MacLennan S, et al: Variability of polymerase chain reaction detection of the bcl-2-IgH translocation in an international multicentre study. Ann Oncol 10: 1349-1354, 1999.

11. Nakamura N, Ohshima K, Abe M and Osamura Y: Demonstration of chimeric DNA of bcl-2 and immunoglobulin heavy chain in follicular lymphoma and subsequent Hodgkin lymphoma from the same patient. J Clin Exp Hematopathol 47: 9-13, 2007.

12. Rambaldi A, Lazzari M, Manzoni C, et al: Monitoring of minimal residual disease after $\mathrm{CHOP}$ and rituximab in previously untreated patients with follicular lymphoma. Blood 99: 856-862, 2002.

13. Sanchez-Vega B, Vega F, Hai S, Medeiros LJ and Luthra R: Real-time $\mathrm{t}(14 ; 18)(\mathrm{q} 32 ; \mathrm{q} 21)$ PCR assay combined with highresolution capillary electrophoresis: a novel and rapid approach that alows accurate quantitation and size determination of bcl-2 JH fusion sequences. Mod Pathol 15: 448-453, 2002.

14. Sanchez-Vega B, Vega F, Medeiros LJ, Lee MS and Luthra R: Quantification of bcl-2/JH fusion sequences and a control gene by multiplex real-time PCR coupled with automated amplicon sizing by capillary electrophoresis. J Mol Diagn 4: 223-229, 2002.

15. Bowman A, Jones D, Medeiros LJ and Luthra R: Quantitative PCR detection of $\mathrm{t}(14 ; 18) \mathrm{bcl}-2 / \mathrm{JH}$ fusion sequences in follicular lymphoma patients. J Mol Diagn 6: 396-400, 2004.

16. Rambaldi A, Carlotti E, Oldani E, et al: Quantitative PCR of bone marrow $\mathrm{BCL} 2 / \mathrm{IgH}^{+}$cells at diagnosis predicts treatment response and long-term outcome in follicular non-Hodgkin lymphoma. Blood 105: 3428-3433, 2005.

17. Darby AJ, Lanham S, Soubeyran P and Johnson PWM: Variability of quantitative polymerase chain reacion detection of the bcl-2-IgH translocation in an international multicenter study. Haematologica 90: 1706-1707, 2005

18. Dessars B, Heimann P, Swillens S and El Housni H: Limitations and practical procedure of bclII-Ig heavy chain gene rearrangement real-time quantitative polymerase chain reaction. J Mol Diagn 8: 133-136, 2006
19. Tysarowski A, Fabisiewicz A, Paszkiewicz-Kozik E, Kulik J, Walewski J and Siedlecki JA: Usefulness of real-time PCR in long-term follow-up of follicular lymphoma patients. Acta Biochimica Polonica 54: 135-142, 2007.

20. Martin S, Fischer C, Free M, et al: LightCycler ${ }^{\circledR}$-based quantitative real-time PCR monitoring of patients with follicular lymphoma receiving rituximab in combination with conventional or high-dose cytotoxic chemotherapy. Eur J Haematol 74: 282-292, 2005.

21. Pennell N, Woods A, Reis M, et al: Association of clinical status of follicular lymphoma patients after autologous stem cell transplant and quantitative assessment of lymphoma in blood and bone marrow as measured by SYBR Green I polymerase chain reaction. J Mol Diagn 8: 40-50, 2006.

22. Csernák E, Tóth E, Melegh Z, Schneider T, Rosta A and Szentirmay Z: Detection and quantification of MBR/JH2 $t(14 ; 18)$ BCL-2 gene rearrangement in follicular lymphoma using a combined real-time polymerase chain reaction. Haematologica 91: 858-859, 2006.

23. Wickham CL, Harries LW, Sarsfield P, Joyners MV and Ellard S: Large variation in $\mathrm{t}(11 ; 14)(\mathrm{q} 13 ; \mathrm{q} 32)$ and $\mathrm{t}(14 ; 18)(\mathrm{q} 32 ; \mathrm{q} 21)$ translocation product size is confirmed by sequence analysis of PCR products. Clin Lab Haematol 28: 248-253, 2006.

24. Mahfouz R, Shammaa D, Tawil A and Zaatari G: Molecular frequency of BCL2/JH t $(14 ; 18)$ using PCR among Lebanese patients with follicular lymphoma: another piece of the geographical map revealed. Mol Biol Rep 34: 271-274, 2007.

25. Slack DN, McCarthy KP, Wiedemann LM and Sloane JP: Evaluation of sensitivity, specificity and reproducibility of an optimized method for detecting clonal rearrangements of immunoglobulin and T-cell receptor genes in formalin-fixed, paraffin-embedded sections. Diagn Mol Pathol 2: 223-232, 1993.

26. Segal GH, Jorgensen T, Scott M and Braylan RC: Optimal primer selection for clonality assessment by polymerase chain reaction analysis: II. Follicular lymphomas. Hum Pathol 25: 1276-1282, 1994

27. Altman DG: Practical Statistics for Medical Research. Chapman and Hall, London, 1991

28. Medeiros JL and Carr J: Overview of the role of molecular methods in the diagnosis of malignant lymphomas. Arch Pathol Lab Med 123: 1189-1207, 1999.

29. Luthra R, McBride JA, Cabanillas F and Sarris A: Novel 5 exonuclease-based real-time PCR assay for the detection of $\mathrm{t}(14 ; 18)(\mathrm{q} 32 ; \mathrm{q} 21)$ in patients with follicular lymphoma. Am J Pathol 153: 63-68, 1998.

30. Limpens J, Stad R, Vos C, et al: Lymphoma-associated translocation $\mathrm{t}(14 ; 18)$ in blood $\mathrm{B}$ cells of normal individuals. Blood 85: 2528-2536, 1995.

31. Summers KE, Goff LK, Wilson AG, Gupta RK, Lister TA and Fitzgibbon J: Frequency of the Bcl-2/IgH-rearrangement in normal individuals: implications for the monitoring of disease in patients with follicular lymphoma. J Clin Oncol 19: 420-424, 2001.

32. Ji W, Qu GZ, Ye P, Zhang XY, Halabi S and Ehrlich M: Frequent detection of bcl-2/JH translocations in human blood and organ samples by a quantitative polymerase chain reaction assay. Cancer Res 55: 2876-2882, 1995.

33. Hoeve MA, Krol AD, Philippo K, et al: Limitations of clonality analysis of B-cell proliferations using CDR3 polymerase chain reaction. Mol Pathol 53: 194-200, 2000. 